\title{
Shrinking of Cities in the Czech Republic and its Reflection on Society: Case Study of Karviná City
}

\author{
Ondřej ŠerýA*, Hana SvobodováB, Zdeněk Šilhan' ${ }^{C}$, Zdeněk SzczyrbaD \\ Received: June 17, 2017 | Revised: January 18, 2018 | Accepted: January 28, 2018
}

DOI: $10.5937 / 22-16622$

\begin{abstract}
The shrinking of cities is a process that accompanies cities in post-conjunctural changes, when they are entering a phase of economic decline and the decline in population connected with it.The OstravaKarviná area is one of the economically problematic regions in the Czech Republic nowadays but it used to be ranked as one of the economic heartlands in the period of socialism. The region, dependent on bituminous coal mining and heavy industry, gradually began to decline after the year 1989 and one of the consequences is a significant decline in its population. This paper deals with identification of the causes and consequences of shrinking cities explained through the example of the town of Karviná through an analysis of quantitative data, questionnaire surveys, and semi-structured interviews. The questionnaire survey revealed that the main reason causing the departure of young and educated citizens is the lack of work opportunities. High unemployment and thus the presence of many socially disadvantaged people causes the atmosphere in the city to deteriorate, and this is accompanied by social problems, such as ageing of the population or criminality. Lack of safety of citizens and a bad environment are other reasons why young people leave the city. The decreasing number of citizens closes the vicious circle by leading to a lower demand for services, closing of shops and other services and increasing numbers of empty houses and flats. Another essential part of the paper is the question of possible measures by the local authority leading to the elimination of these undesirable phenomena, but also the belief in the necessity of help from the government.
\end{abstract}

Keywords: shrinking city; depopulation; Karviná; economically problematic region; questionnaire surveys; semi-structured interviews

A Department of Geography, Faculty of Science, Masaryk University, Kotlářská 2, 61137 Brno, Czech Republic; ondrej.sery@mail.muni.cz

B Department of Geography, Faculty of Education, Masaryk University, Poříči 7, 60300 Brno, Czech Republic; 67632@mail.muni.cz

c Department of Regional Economics and Administration, Faculty of Economics and Administration, Masaryk University, Lipová 41a, 60200 Brno, Czech Republic; z.silhan@mail.muni.cz

D Department of Geography, Faculty of Science, Palacký University Olomouc, 17. listopadu 12, 77146 Olomouc, Czech Republic; zdenek.szczyrba@upol.cz

* Corresponding author: Ondřej Šerý, e-mail: ondrej.sery@mail.muni.cz 
Throughout the whole period of their existence, the development of cities has been connected with an increase in the size of their population or area. Economic, political, and other stimuli led to increases in their importance in history; they slowly became centres of political power and economic heartlands. On the other hand, cities distinguished by a decrease in their population and gradual loss of importance appeared in the USA and Western Europe, approximately in the mid- $20^{\text {th }}$ century. A discussion started on "decreasing" or "shrinking" cities (Martinez-Fernandez et al., 2012). It is a relatively new phenomenon in the post-Soviet states of Eastern Europe (Popes-
$\mathrm{Cu}, 2014)$, because it has been made possible by closer links with the West, when the Communist regime fell at the turn of the 1980s and 1990s, and the transition from a centrally planned economy to a market economy. The goal of this paper is to characterise the process of "shrinking cities" in the Czech conditions. The perception of the process of shrinking, from the point of view of citizens, is expounded by a case study of a specific town - Karviná - and the causes and consequences of the shrinking were identified by means of semi-structured interviews with local people, along with an evaluation of possible approaches to a solution to this negative phenomenon.

\section{Context of the shrinking of cities and regions}

When we look carefully at the development of cities over the last two or more centuries, it is obvious that it was industry which brought dramatic population and economic development to some cities and population and economic decline to others. However, the shrinking of cities is not connected only with industry; its history is actually much older and is connected with a whole range of changes in the settlement system of many countries around the world, as a result of war events or illnesses (Hollander et al., 2009).

An explanation of the word shrinking may seem comprehensible at first sight, i.e. something like thinning or decreasing of cities from the demographic point of view, whilst in reality it is a far more complicated socioeconomic and spatial process. Apart from the decline of the city's population, it is also about political, economic, or other kinds of urban decline within the hierarchy of the settlement system (Rumpel \& Slach, 2012). The shrinking of cities does not directly express a phase of degradation in their development; nevertheless, some authors operate with terms that have negative connotations, e.g. "urban decline" (Clark, 1989), "urban blight" (Couch et al., 2005) or "urban crisis" (Fishman, 2000). The causes of this decrease are as varied as the cases of cities that are studied are frequent. The shrinking of cities does not have an easy or universal explanation. It is a highly complicated phenomenon, which is dependent on economic, political, and social conditions (Hasse et al., 2014).

A long-term decline in population is usually, in the majority of cities, followed by negative phenomena: people react to a crisis in their local economics because of the decline of traditional industrial sectors. Important changes in economic structure and demographic changes caused, besides other things, by ur- ban citizens moving into suburban areas, lead not just to the shrinking of cities but also to a change in their quality. It has been proved that a high rate of population decline is closely connected with a decrease in the size of settlements or with an increase in the factor of periphery and rurality of space, while there has been expansion in contiguous metropolitan areas (Cawley, 1994; Kupiszewski et al., 2008; Westlund \& Pichler, 2012). Population decline in cities is often a consequence of increased migration of young people to the countryside near these cities and also their moving for work-related reasons into economically more successful cities and regions of the given country. The shrinking of cities and regions is influenced not only by migration (emigration) but also by variations in the ages of migrants. After the process of political and economic transformation the migration pattern changed significantly. People aged 35-50 now move more often to suburban or rural areas, younger people aged $25-35$ prefer urban areas and older people aged 50-70 move more often into rural areas (Šimon 2014).

The process of long-term decline in the population of cities is particularly typical of industrially developed countries. It is also typical of countries in which urbanisation has reached its ceiling and thus there is no space for a further increase in the share of the urban population. The rate of urbanisation has reached $90 \%$ in the USA and the UK, and around $70 \%$ in many European countries, including the Czech Republic (Schmeidler, 2012). Even though population decline is considered a key indicator of change, it cannot be considered the main cause of the shrinking of cities and regions. Rumpel and Slach (2012) recommend operationalising the shrinking via other indicators, e.g. the share of uninhabited or unoccupied flats (houses), stagnating or 
even decreasing prices of property as a result of an excess of supply compared to demand, or social, industrial, and infrastructure brownfields as a consequence of lower usage of urban areas. A typical instance of a shrinking city is one that went through structural changes in industry, which leads to a decline in the working classes and also to a decrease in the population of citizens. The ascendancy of one sector, in combination with a failure to keep up with technological progress and the increasing importance of the tertiary sector, has become an encumbrance for many cities in the USA and Western Europe (Martinez-Fernandez et al., 2012); Wiechmann \& Pallagst, 2012). There is often a decline in the population on a regional level in industrial regions in developed countries (Hudson, 2005; Polèse \& Shearmur, 2006), but also in rural and peripheral areas (Ganser \& Piro, 2012). Population losses in the countryside are mostly caused by young people moving into cities as a result of an unfavourable situation in the local labour market. Most of the previous research which has been done on the topic (Oswalt \& Rieniets, 2007; Turok \& Mykhnenko, 2007; Haase et al., 2013, 2014; Wiechmann \& Pallagst, 2012; MartinezFernandez et al., 2012; Stryjakiewicz, 2014) is related to three basic levels of discussion:

1. Does "shrinking cities" refer only to depopulation, or must there also be other indicators (e.g. a structural crisis of the economy in combination with a high level of unemployment, decrease in housing capacity, and a high accumulation of social problems)?

2. Does population decline only occur within the boundaries of an administrative area? Can cities that have growth in peripheral areas (as a result of suburbanisation) be considered shrinking cities?

3. For how long must a period of population decline last for the term "shrinking cities" to be appropriate?

Not all cities in Europe are shrinking. There are various reasons why some cities attract citizens, while others, on the other hand, lose their population. 370 cities with more than 100,000 citizens lost more than $10 \%$ of their population in the last 50 years (Oswalt \& Rieniets, 2007). The majority of cities started to lose their population in the 1980 os and 1990s. As many as one third of European cities with more than 200,000 citizens went through a decade of population loss at least once in the last 45 years (Turok \& Mykhnenko, 2007). The CIRES research study (2013), which provided a detailed analysis of population changes in more than seven thousand cities in Europe (7035) with more than five thousand citizens (including contiguous settlements) in the period 1990-2010, showed that the process of the shrinking of European cities differed significantly. Those that were considered shrinking cities were the ones with a number of citizens which decreased minimally per year (-0.15\%). "Just" $20 \%$ of shrinking cities were found in the set. The countries of Central and Eastern Europe had the highest proportion of shrinking cities from a regional point of view. On the other hand, for the states of Western Europe it was typical to have a high share of growing cities (Stryjakiewicz, 2014). The development of cities used to be connected, in classic urban studies approaches, with their increase, growth, and expansion. It is necessary to react to this change and to adapt the management and planning tools with respect to the sustainability of urban development in the new postindustrial phase of development, when cities are losing citizens in the long term (Schmeidler et al., 2011).

Buček (2016) emphasises that the politics of urban development is a multi-hierarchical activity including diverse participants from the public, private, and nonprofit sectors, which functions at local (sub-local), regional, national, European, and world levels. We are aware of examples in other countries that demonstrate the possibilities of effective urban planning during a period of shrinking, not just by involving a wide range of people capable of commenting on the problems of the management of shrinking cities (Shetty, 2009; Marotta, 2011), but also by searching for new planning approaches. This is known as the "ecologisation of urban space" (Allweil, 2007; Hollander et al., 2009). The aim of these approaches is to make shrinking cities more attractive for potential citizens, to encourage community-oriented planning, and, last but not least, to modernise the infrastructural networks in these cities. These approaches are not discussed further here due to the character of our paper. Shrinking has become a normal development for many European cities and urban regions, according to research and the current experience of urban and regional projecting (abroad) (Rumpel \& Slach, 2014). On the other hand, the urban policies of developed European countries, based on activities which reduce the impact of the shrinking of cities, are not exclusively a matter for the private sector. On the contrary, when it comes to solving urban and regional problems in the post-Soviet countries of Central and Eastern Europe, where the shrinking of cities and regions is a relatively new phenomenon, the public sector has a key role. It will take a while for the public sector to accept the trend of shrinking cities and its economic, social, and spatial consequences. Buček and Bleha (2013) agree with this condition and note that regardless of the reality of the development that has been mentioned, only a minor acknowledgement of "shrinkage" exists in the planning documents of Slovak cities. Local elites do not sufficiently accept the shrinking process and the prevailing practices of the expansion-oriented planning of urban development continue. 


\section{Identification and classification of shrinking cities in the Czech Republic}

In the Czech Republic, the problem of shrinking cities has not yet been comprehensively dealt with. There are some individual studies or specialised articles dealing with the shrinking of cities (e.g. Rumpel \& Slach, 2012; Rumpel et al., 2012; Rumpel et al., 2013; Rumpel \& Slach, 2014; Rink et al., 2014), and, peripherally, Krejčí et al. (2009), along with social aspects of research on city issues (Sýkora \& Ouředníček, 2007; Sýkora, 2012, and others). Taking into consideration the fact that the Czech Republic has a characteristic settlement structure (Illner, 20o6; Ouředníček et al., 2011) and its historical development is different from the states of Western Europe or the USA, it was not possible to use current methods for the delimitation of shrinking cities. Therefore, within the research project TBо30MMRoo2 Shrinking Cities and Regions in the Czech Republic, a Methodical Identification of the Causes of the Shrinking of Municipalities and Regions (Svobodová et al., 2015a) was created, which determines one of the possible approaches to a definition of shrinking cities and their classification.

The methodology is based on the intensity of shrinking and development, not just in a city itself but also in its hinterland. The identification of settlements to which this issue is relevant was the first step within the solution of shrinking cities in the Czech Republic. For this purpose, a database of all Czech municipalities was created with relevant data which is related to the causes and consequences of this phenomenon. The period of population decline that was analysed was delimited in the period of the formation of the methodology to the years 2004 and 2014; it is also possible with a more recent ten-year period. In the whole ten-year period 2004-2014, 1,742 municipalities out of the 6,253 which existed in the Czech Republic on January 1, 2014 had a population decline. The number of citizens in the above-mentioned entities on Jan- uary 1, 2009 was subsequently established. In the period from 2009-2014, 1,375 municipalities registered a population decline. Considering that the research is focussed on shrinking cities and not on municipalities, it was decided to work only with municipalities which had more than 3,00o citizens on January 1, 2014. The reason was that the law no. 128/200o Coll., on municipalities (the Municipal Arrangement) states in $\$ 3$ that "a municipality which has at least 3,000 citizens is a town, if the President of the Chamber of Deputies determines it, after a statement of the government and a proposal from the municipality". This condition was fulfilled by 239 municipalities which, at the same time, showed a population decline in the years 20042014 and 2009-2014. The last step in defining the primary statistical population of the shrinking cities of the Czech Republic was to determine a criterion of a population decline of at least $3 \%$ in the years 2009 until 2014, in order to prevent the classification of municipalities which had just a minimal decline in their number of residents, and thus were more "stagnating cities" than shrinking cities. 111 cities fulfilled this condition.

The second step was the taxonomy of shrinking cities. The inspiration for the creation of the typologisation was adopted from the project "Cities Regrowing Smaller" (COST Action CIRES), undertaken in the period 2009-2013 by researchers from 26 European countries (and Australia), which determined three primary types of shrinking:

Type A: Long-term/Continuous Shrinkage

Type B: Irregular/Episodic Shrinkage

Type V: Time-limited/Temporary Shrinkage

Considering the specifics of individual territories in the Czech Republic, the process of the creation of the typologisation was determined as shown in the following chart:

Table 1. Typology specification according to the different rate of development of the territory

\begin{tabular}{|l|l|l|}
\hline & $\begin{array}{l}\text { Population decline on territory } \\
\text { between } 2004 \text { and 2014 }\end{array}$ & $\begin{array}{l}\text { Population increase on territory } \\
\text { between 2004 and 2014 }\end{array}$ \\
\hline \multirow{2}{*}{$\begin{array}{l}\text { Long-term population decline, } \\
\text { i.e. in the periods 2004-09 and } \\
\text { 2009-14 }\end{array}$} & $\begin{array}{l}\text { Type 1a (7 cities) } \\
\text { territory decline by 3\% and more }\end{array}$ & $\begin{array}{l}\text { Type 2a (23 cities) } \\
\text { territory increase by 3\% and more }\end{array}$ \\
\cline { 2 - 3 } & $\begin{array}{l}\text { Type } 1 \mathrm{~b} \text { (25 cities) } \\
\text { territory decline from 0 up to 3\% }\end{array}$ & $\begin{array}{l}\text { Type 2b (17 cities) } \\
\text { territory increase from 0 up to 3\% }\end{array}$ \\
\hline \multirow{2}{*}{$\begin{array}{l}\text { Short-time population decline, } \\
\text { i.e. just in the period 2009 until } \\
2014\end{array}$} & $\begin{array}{l}\text { Type 3a (3 cities) } \\
\text { territory decline by 3\% and more }\end{array}$ & $\begin{array}{l}\text { Type 4a (16 cities) } \\
\text { territory increase by 3\% and more }\end{array}$ \\
\cline { 2 - 3 } & $\begin{array}{l}\text { Type 3b (6 cities) } \\
\text { territory decline from 0 up to 3\% }\end{array}$ & $\begin{array}{l}\text { Type 4b (14 cities) } \\
\text { territory increase from 0 up to 3\% }\end{array}$ \\
\hline
\end{tabular}

territory = administrative district with extended powers in which the shrinking city belongs, excluding the shrinking city itself Source: Svobodová et al. (2015b) 


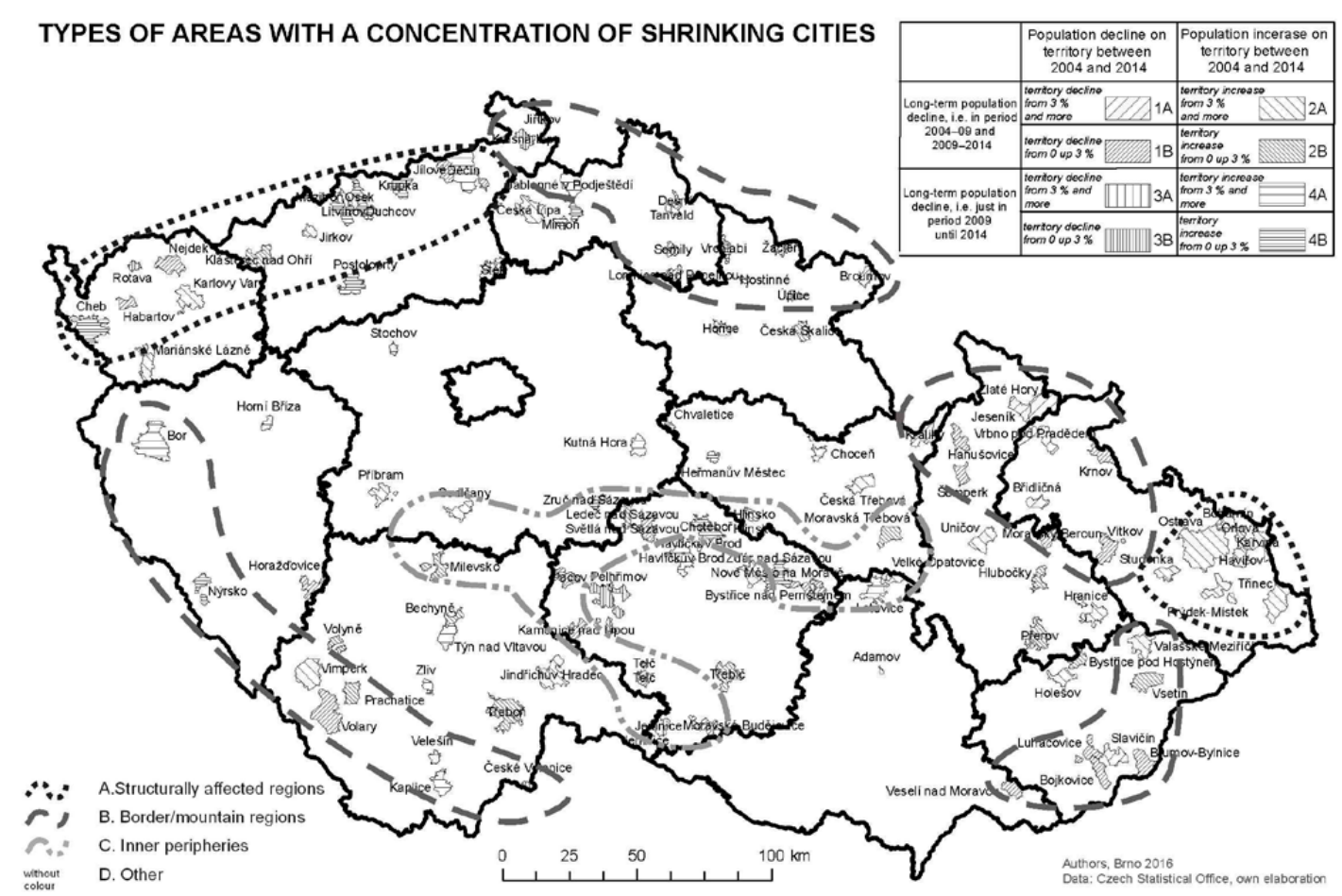

Figure 1. Types of areas with a concentration of shrinking cities Source: GaREP, spol. s r.o. on the basis of Czech Statistical Office data

The result is the identification and typologisation of 111 shrinking cities in the Czech Republic, of which 46 lie on the territory of economically problematic regions determined in the Strategy of Regional Development of the Czech Republic 2014-2020 (Ministry of Regional Development of the Czech Republic, 2013, p. 150). The biggest continuous territories of economically problematic regions are in NorthWest Bohemia and the Ostrava area (structurally affected territories - regions with long-term and extensive mining activities and heavy industry) and in the northern part of the republic (border/mountain areas - outlying territories near borders and mostly with a landscape with a mountainous character).
The long-term depopulation of cities is still mostly an issue in Moravia - particularly in the areas of the so-called inner periphery, often lying on regional borders. Other shrinking cities are situated on the above-mentioned territories, where another combination of territorial factors is at work. We can find more important concentrations of cities, such as those in the central part of the South Bohemian region, in the northern part of the Pardubice region, and in the south-eastern part of the Olomouc region (including the north-western parts of the Zlín region). A significant factor is also bankruptcy (reduction of production) of a predominant employer or a sector (e.g. Adamov, Třebíć, or Přerov).

\section{Methodology of the case study}

The town of Karviná, which lies in the north-eastern part of the country, in the Moravian-Silesian region, was chosen as a case study of a shrinking city in the Czech context. Karviná is a part of the wider OstravaKarviná agglomeration, which in the period of socialism was one of the economic heartlands of the state. Its economy was based almost only on bituminous coal mining and associated branches of heavy industry (e.g. metallurgy, heavy engineering, or chemical manufacturing). Within the process of transformation, the whole region was affected and Karviná itself is one of the towns with the highest population decline (Martinát et al., 2016). There were 67,568 people in the town in the year 1994; however, twenty years later, in 2014 , there were 56,848 people registered in Karviná, i.e. during this time the population decreased by $15.9 \%$. The depopulation was caused mainly by migration; nevertheless, the population growth is negative.

A questionnaire survey was performed with people in Karviná in the form of personal interviews in May 2015. 880 completed questionnaires were obtained 
from citizens aged 18 years old and higher, thus guaranteeing a level of importance of $95 \%$ and a maximum deviation of $3.5 \%$.

The sample was also representative with regard to the structure of the citizens according to their gender, age, and the highest level of education they had reached. The results that were obtained were subsequently rewritten into an online form created in the Google Docs application. The questionnaire contained 15 mostly closed questions; in one question the respondents were able to react on an attitude scale (evaluation on a Likert scale from 1 to 5 or the option "no idea"). In some questions it was possible to choose the option "other" and provide one's own answer. The last five questions were for the purpose of demographic identification. The results of the survey were evaluated according to primary quantitative methods; analysis by means of key words was used in the case of the open questions. Questions relating to the causes and consequences of the shrinking of Karviná, or measures against this undesirable phenomenon, were examined through semi-structured interviews. This type of interview does not have questions formulated in advance and arranged in strict order. Hendl (2008) calls it an "interview according to instructions", in which the instructions (i.e. a list of questions or rather topics) provides what it is necessary to discuss during the interview. The questioner is responsible for the way of obtaining information and the order it is obtained in, thus allowing adjustments according to the actual situation. On the one hand the "guide" helps the questioner to stick to the topic (research question), while on the other hand it gives sufficient space for the interviewees to express themselves from their own point of view and not to be too bound by the options that are on offer or too limited by a thematic focus. Disman (2011) uses the term "non-standardized interview", where the key interaction is between a questioner and an interviewee, because the questioner has just a general plan (skeleton) prepared in advance. The answer to a previous question acts as a stimulus for a new question and the interviewee becomes a co-author of the research, or rather a co-creator of the formulation of the question. Using this method, the key questions and choice of the right interviewees are naturally crucial. With regard to the key question, it was gradually formulated in this final form: "In what way does the process of the shrinking of the town of Karvina' present itself?" The ways in which a local authority can combat shrinking were central topics and therefore a subsidiary research question was also formulated: "What kind of measures can the local authority of Karviná take against its shrinking?" In the first part, the interview dealt with an evaluation of the development of Karviná in the last 10 years from the point of view of the interviewees. This was followed by thematic sections which dealt with the everyday consequences of a shrinking city, the causes of this phenomenon, and the conditions for the development of Karviná in comparison with the surrounding towns. In the second part the document concentrated on the conceptual documents of the town and on possible tools the town can use to combat shrinking, and on the suitability/necessity of the potential involvement of the regional authorities or the state. In May 2015 five semi-structured interviews were conducted with individuals who can be marked as participants in the development of the town of Karviná and have a direct relationship to the topic of the shrinking city. They were the deputy mayor of the town, the deputy director of the contact department of the Labour Office of the Czech Republic in Karviná, an expert on regional development from the local Silesian University (School of Business Administration), the deputy director of an important private company in business in Karviná, and the deputy director of a local nongovernmental non-profit organisation. The interviews were conducted in offices at the departments of the above-mentioned individuals, and with their consent were all recorded on a voice recorder. Each interview lasted 45 minutes on average. They were rewritten into textual form, coded, and analysed; the main goal of the thematic analysis was the coherence of its findings with the research question (in other words: the findings should answer the research question in some way) and these findings should be obviously supported by the collected data, or rather build on them (Silverman, 2005).

\section{Questionnaire survey of inhabitants of Karviná}

Within the survey 880 questionnaires were obtained, of which 434 were from men (49.3\%) and 446 from women $(50.7 \%)$. The age of the respondents had to be higher than 18 years. The age structure of the respondents was as follows: $21.6 \%$ of the people were aged $18-$ 29 years, $23.2 \%$ 30-44 years, 27.3\% 45-59 years, and $21.6 \%$ of the people were older than 60 years. Their ed- ucation quite closely resembled the structure of education of the general Czech population, as most of the respondents had secondary education with a schoolleaving examination (40.3\%) or secondary education without a school-leaving examination (31.6\%). Due to the location of the survey, there was a higher share of people with just primary or unfinished education 
(16.4 \%) and just $11.7 \%$ of the respondents had tertiary education. With regard to the economic activity of the respondents, employees of the tertiary sector predominated. There was also a high share of respondents employed in industry, which reflects the industrial focus of the region, which is mainly on coal mining and the manufacturing industry. A high share of the respondents were retired people, who comprise an ever-growing share of the population, which in Karviná is exacerbated by the departure of young and qualified people from the town. $11.3 \%$ of the respondents were students who were studying in Karviná at the School of Business Administration, which is a part of the Silesian University in Opava.

Almost half of the respondents (47.9\%) answered the opening question, which was "What do you consider living in Karviná to be like?", by stating that it is good (really good or rather good). Living in Karviná was rather bad or really bad for $25.2 \%$ of the respondents.

The respondents had the opportunity to evaluate Karviná with marks from $1-5$ ( 1 is the best, 5 is the worst) with regard to several aspects of life in the town. Out of the areas that were mentioned, the services and shops available did best $(65.1 \%$ of all the respondents gave a mark of 1 or 2 , and the average mark was $2.3)$, followed by public transport $(61.9 \%, 2.2)$ and care for public spaces $(58.8 \%, 2.4)$. On the other hand, the worst were the work opportunities $(69.3 \%$ of all the respondents gave a mark of 4 or 5 , and the average mark was 4.0$)$, the safety of citizens $(63.8 \%, 3.8)$, and the bad environment $(46.5 \%, 3.4)$. The views on citizens' safety and work opportunities were analysed according to the age of the respondents and the highest level of ed- ucation they had reached. Among those with primary and secondary education without the school-leaving examination, the most disappointed citizens were of a higher age, from 45 years and up. Among those with secondary education with the school-leaving examination, on the other hand, the most disappointed respondents were those aged up to 44 years, the same as with university-educated ones. Similarly, opinions about safety vary.

The respondents were asked to express their opinion about evidence of the depopulation of Karviná in the daily life of the town. Overall, 88 respondents mentioned the departures of (young and qualified) people and an empty town. Next, they often mentioned (in 78 cases) the deterioration of the social situation in the town being caused by the presence of Romani people, which is, in their opinion, connected to a decrease in safety and an increase in criminality. Other evidence, according to 60 respondents, is shown by vacant apartments. Also mentioned were the aging of citizens ( 42 answers), a worse atmosphere in the town ( 25 answers), and fewer customers, fewer services, and the closing of shops connected with this ( 25 answers).

The respondents also reacted to the question whether they had ever considered moving out of Karviná. Almost 55\% answered that they were considering or had considered it. A minority (43.8\%), on the contrary, answered negatively.

Altogether, 276 respondents who wanted or want to move from Karviná mentioned jobs as their main reason. Other reasons appeared less frequently - family reasons were mentioned in 40 answers, the bad environment and air in 39 answers.

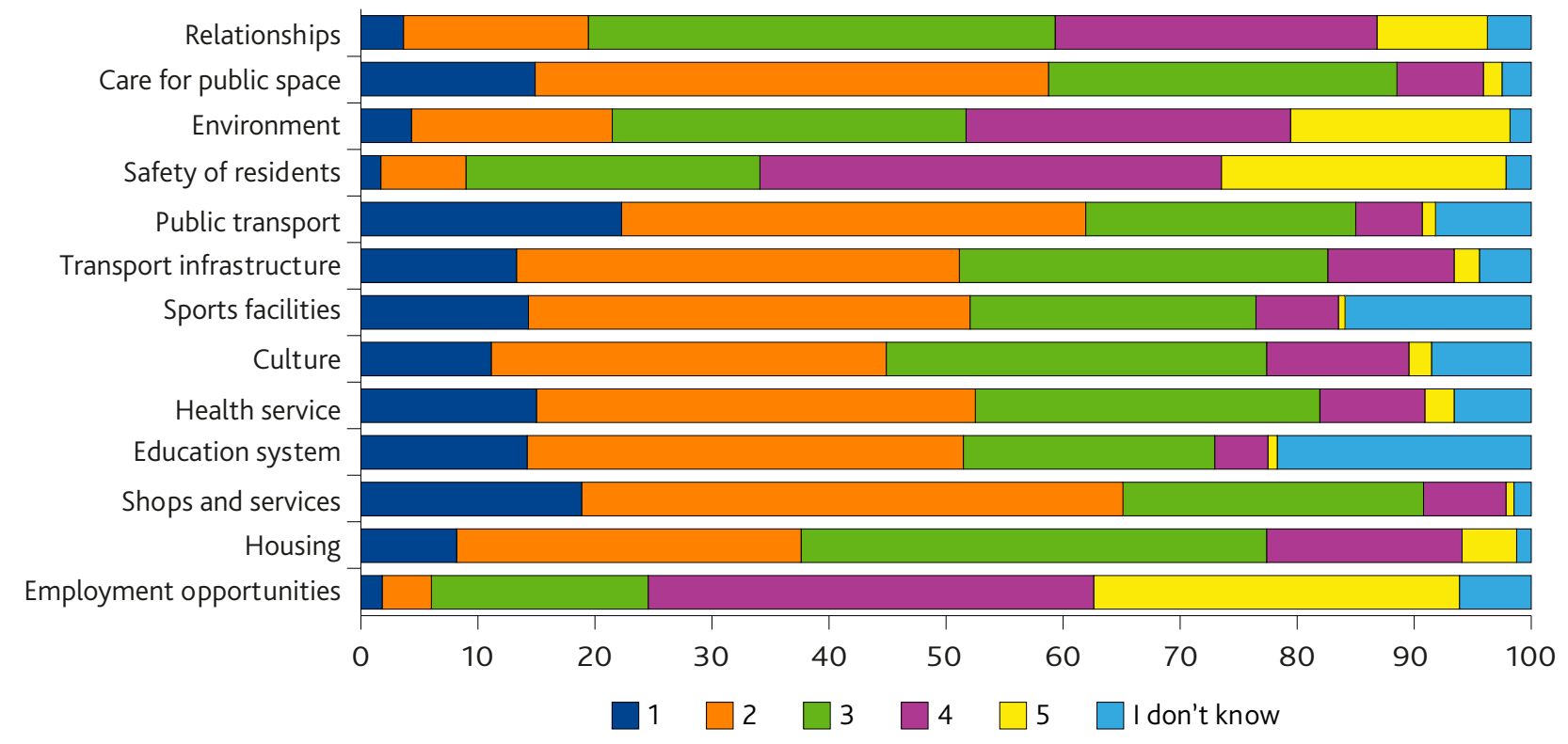

Figure 2. How would you evaluate Karviná from your point of view in the areas listed below? $(n=880)$ Source: Svobodová et al. (2015b) 
Departures (of young qualified) people, empty city

$$
\begin{array}{r}
\text { Many Romani } \\
\text { Vacant flats } \\
\text { Aging population }
\end{array}
$$

The atmosphere in the city, bad relationships between people

Few customers, few services, closing stores

Lack of jobs

Criminality

Not at all

Other

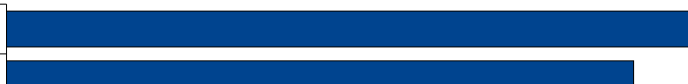

\section{-}
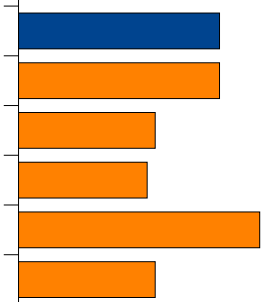

$\begin{array}{llllll}0 & 20 & 40 & 60 & 80 & 100\end{array}$

Figure 3. How does depopulation in Karviná influence everyday life in the town? $(n=462)$

Source: Svobodová et al. (2015b)

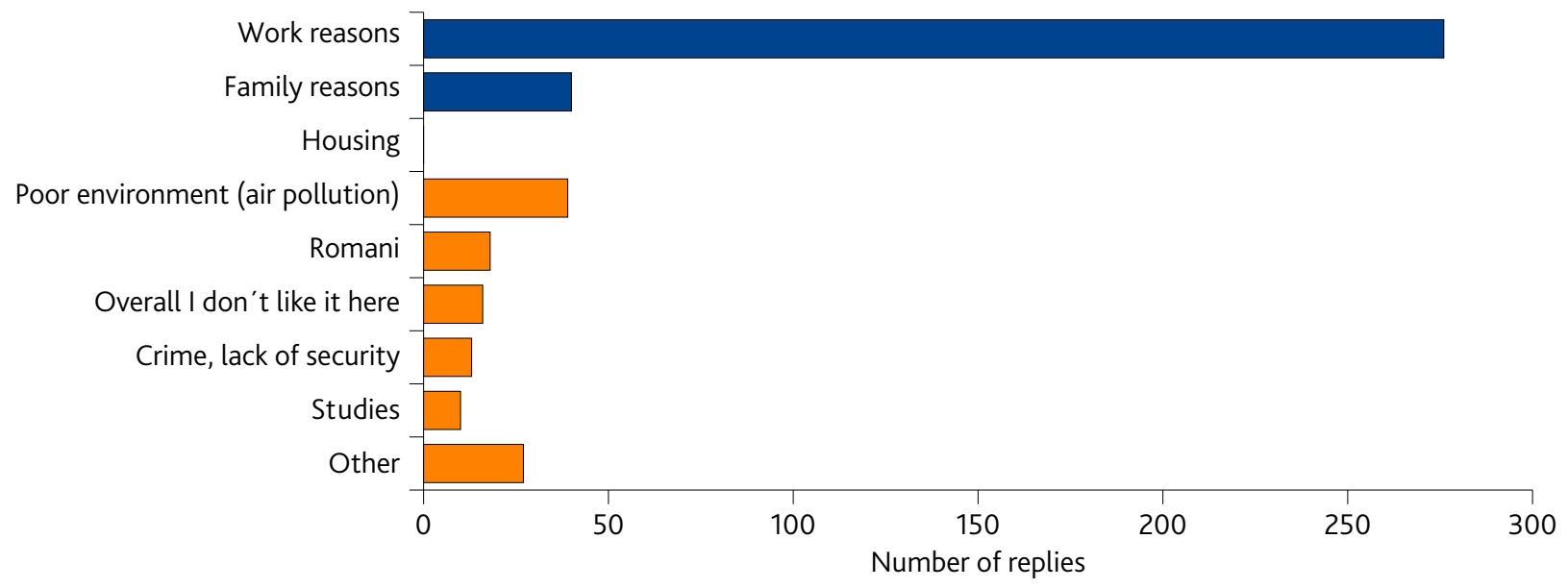

Figure 4. For what reason have you considered/are you considering moving out of Karviná? $(n=480)$ Source: Svobodová et al. (2015b)

Those respondents who wanted to move but decided to stay in Karviná in the end did so in 134 cases because of their family, in 68 cases because of work, and 29 respondents stayed because of a lack of finances. Other reasons, such as advanced age (22 an- swers) or habit (19 answers), were mentioned less often.

The respondents had the option to file a recommendation as to what the municipal authority of the town of Karviná should do to combat depopulation. Altogether,

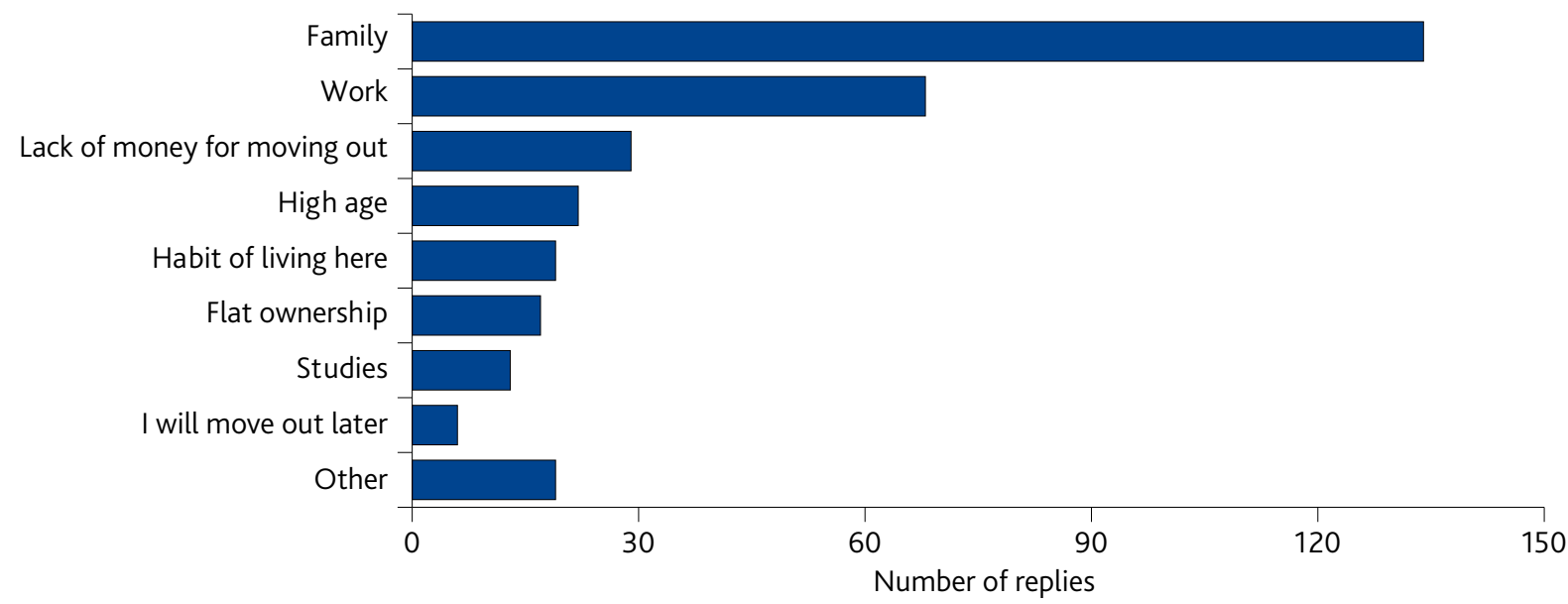

Figure 5. For what reason have you decided to stay in Karviná? $(n=290)$

Source: Svobodová et al. (2015b) 


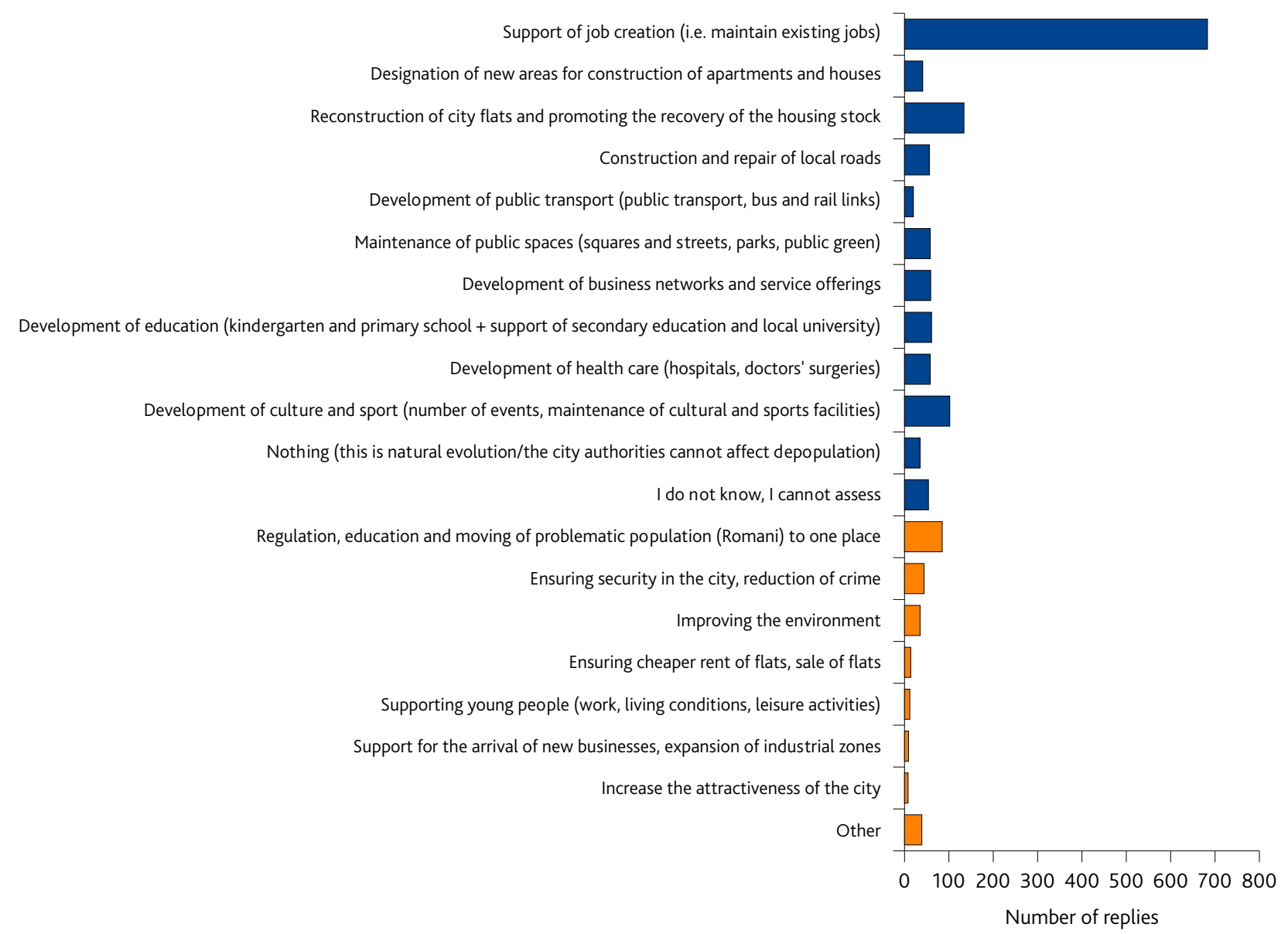

Figure 6. What should the municipal authority of Karviná do to combat depopulation? $(n=880) w$

Source: Svobodová et al. (2015b)

$77.9 \%$ of the respondents asked for support for the creation of job opportunities. $15.2 \%$ recommended the reconstruction of city apartments and support for renewal of the housing fund. The development of culture and sport was in third place with $11.6 \%$. In $9.7 \%$ of cases people also mentioned problems with the Romani people and recommended educating Romani people and regulating and moving them into specific localities.

The questionnaire survey among the citizens showed that one of the most important needs of the citizens of Karviná nowadays is the need for a job. However, there is a high proportion of unemployed people and issues with a further loss of jobs related to the planned reduction of coal mining. Nevertheless, one solution could be the expansion of the industrial zone and enticing a big investor.

The open answers often mentioned safety and increased criminality, which, according to the respondents, is often related to an excessive concentration of Romani people in some parts of Karviná. According to respondents, this is often caused by living allowances for socially disadvantaged citizens. The main private property owner in Karviná takes advantage of it and he moves socially disadvantaged people into specific places. Another frequently mentioned problem is the environment, mainly air pollution.

\section{Semi-structured interviews with local players}

Within the semi-structured interviews, too, all the interviewees, who were important players in the development of the town, agreed that the primary problem of the town of Karvina is the lack of job opportunities. In addition, they pointed out that the key (biggest) employer in the town is a mining company which is gradually reducing its activities, and the number of unemployed people will be rather higher. There is a related question as to whether to support the mining somehow and delay its end, or to decide on a relatively quick closure of the mines, which is expected anyway in the close future. The respondents did not have unequivocal attitudes to this.

"I perceive mining more negatively for the town; the sooner it ends, the better it will be for the development of the region, in hindsight. ... I do not see any vision, 
mainly the long-term one. Even though I understand that they cannot say we will close the mines now and it is going to be better in 10 years" (specialist in regional development, School of Business Administration in Karviná).

The next problem, which is related to unemployment, is that it is mostly young people with higher education who leave the town. According to the statements of the interviewees, it is typical that young people leave for university education in cities with larger populations - such as Ostrava, Brno, or Prague - and they do not come back. What is also important is that it is not only the category mentioned above, but people in general who are marked as "capable", "assertive", "skilled at languages", "productive", or "who have achieved something", and thereby the town loses its almost irreplaceable social capital. The declared effort of the local authorities and other institutions is to create an environment in the town which would make Karviná attractive for further life at least to some extent.

"We do a lot of things for seniors and children, but there is a lack of activities for the category from 15 to 30 years old. Thanks to European money we were able to create a project "Journey to town", the main goal of which is to awaken pride in where people come from.... We try to get together with youngsters and communicate to them that they can leave for their studies and then come back and be proud of this region" (Deputy Mayor, Karviná Municipal Council).

As already mentioned several times, people tend to leave Karviná. But the interviewees pointed out that a certain number of people arrive in the town. However, according to their statements this group of people is marked as "maladjusted", "socially disadvantaged", or "Romani people" (one of the respondents spoke directly about a "Romani town").

According to them, this fact increases the share of abandoned residential and non-residential spaces, which afterwards become an item for the trade in social housing and their accommodation. According to their words, Romani groups do not happen just to be concentrated in the town, but are also segregated and mostly create a subjective feeling of danger and risk, which, after all, confirms the results of the questionnaire survey. The respondents further pointed out that this does not have an influence just on the perception of safety, but also on the development of the local economy, because this again reduces the attractiveness of the town from the point of view of investors. They also overwhelmingly agreed on the opinion that a reform of social policy is necessary, which would provide greater motivation to gain profit and to cease dependency on social benefits on the one hand, and to change the opinion of the public that there is unfair (undeserved) subsidising at the expense of employed citizens on the other. Nevertheless, the solution of social policy is in the hands of the state. It is necessary to add that it is an aspect strongly influenced by socially biased interpretation of reality.

"We have enough buildings of our own and belonging to businesses that are empty, there is low purchasing power, and plenty of vacant apartments belonging to private owners, and this attracts maladjusted people, which has an influence on safety and the economic aspect of the town" (Deputy Mayor, Karviná Municipal Council).

In the statements of the interviewees about possible solutions and measures within the fight against the shrinking of the city, the view was often expressed that help at the state level is necessary. Words were uttered about a "change in the determination of taxes from the budget for structurally affected areas", "state investments", "investments for industrial zones from the side of state institutions", or "higher support for economically weak regions".

The next tool for achieving an improvement in the current situation is, according to the respondents, a change in the media image of the town, which hides its significant potential. According to their statements, Karviná is still connected with "mining", "mines", and "a polluted environment", which does not provide any reason for a visitor to go there, or possibly think of moving or relocating/founding a company. Nevertheless, the respondents consider important positives to be the presence of a spa, the significant improvement of the environment in the last twenty years, and good transportation or connections with Slovakia and Poland.

"What do you think of when Karviná is mentioned? It does not present itself as a pleasant town. What is the use of the Darkov Spa being nice when it is not presented well? Until somebody comes here, does anybody recall the connection of "Karviná as a spa town"? Absolutely not. Mine shafts, yes, but not the spa" (Deputy Director of non-governmental non-profit organisation from Karviná).

Within the interviews the respondents often mentioned the passivity and low level of engagement of the local citizens, which, according to them, emerged from the local social and cultural capital. They spoke about "the heritage of socialism", "nostalgia", "poor identity", "weak connection with the area", and especially "fatalism". Poor engagement in public life was named as a major problem leading to insufficient interest in the further fate of the town, but also to a reduction in its overall attractiveness (influence on the social life of the town, creative environment).

"The problem is that local people have a lack of education and few prospects and they have not worked 
much anywhere else. Some point out that people do not protest much against this negative development here. When Thatcher was closing the mines at the beginning of the 1990s 100,000 people lost their jobs here and it was just accepted. I see a close connection with education and tradition, also in the period after the fall of socialism people were willing to be more modest. This is typical of this region, such fatalist belief that an employer will come, but maybe he/she will not. Resignation is a good word" (specialist in regional development, School of Business Administration in Karviná).

When speaking of other developments in the town, another opinion started to appear, that it is necessary to accept that there is a specific trend in the case of (former) "mining towns/cities" which cannot be changed and that is necessary to forget the possibility that the population decline will once again be turned into an increase. They see as important some reconciliation with destiny and acceptance of the necessity to concentrate on the stabilisation of the current number of citizens and therefore almost exclusively on those citizens who (in the meantime) have not left yet. However, this approach to thinking will require steps which are not yet common in the Czech environment, but which are being taken in other countries (especially in the West). The interviewees mentioned, for instance, the relocation of families, so that individual apartment buildings would be more or less occupied, while it would be necessary to demolish the rest of the empty ones and, for example, make parks instead of them (i.e. basically rationalising housing and the residential fund).

\section{Conclusion}

The town of Karviná is a typical example of a town which is situated in a structurally affected area in the Czech Republic. These areas have very similar features. These are regions which were exposed to significant structural changes within the transformation of the Czech economy from a centrally planned economy to a market economy, in particular the decline of the extraction of mineral resources. And these areas also have issues with overall economic stagnation and lack of opportunities, which also implies the departure of mainly young and qualified citizens.

When examining the shrinking of Karviná we experienced a strong desire for the cultivation of an environment for life and the creation of a positive environment for business on the side of the municipality and building a positive image of the region in relation to this. Regarding possible changes on the level of the state, in the conducted questionnaire survey and the interviews changes were suggested in the budgetary determination of taxes and in greater public investment. They formulated a demand for the adjustment of the social policy of the state. It is apparent through the case study of the town of Karvina that cities are not reconciled to shrinking and that tendencies and efforts exist to reverse this process back to a pro-expansion tendency. Many cities abroad are reconciled to shrinking and there are known instances that show the possibilities of effective planning and development of cities as they shrink, not just through the involvement of a wide range of participants able to express themselves with regard to the issues of controlling shrinking cities (Shetty, 2009; Marotta, 2011), but also by searching for new planning approaches, which can overall be called the "ecologisation of city territory" (Allweil, 2007; Hollander et al., 2009). One of the key tasks for the future is to manage to deal with the complex consequences of processes of demographic, economic, and physical settlement and to learn how to plan cities (especially small ones) (Hollander et al., 2009).

The problem of shrinking cities is a very varied issue; to put it simply, each city has a different set of causes and consequences, or factors determining its shrinking and possible measures to eliminate this undesirable phenomenon. The image of a given city plays a significant role. It is more and more obvious that the key factors are mainly the conditions in the local labour market and the preferences of the young generation. The localisation of important employers is a strategic factor in the development of cities. The chance of gaining work, feeling safe in a city, or evaluating the condition of the environment appear to be suitable routes to halting (or at least slowing down) population decline for cities in the Czech conditions.

\section{Acknowledgement}

This paper was processed within the projects of Masaryk University MUNI/A/1251/2017 and MUNI/A/o976/2016. The authors are grateful for the support received from the students' grant project titled 'Socio-economic structures and determinants of the contemporary landscape: analysis and interpretation of geographic reality" funded by the Palacký University Internal Grant Agency (IGA_PrF_2017_021). 


\section{References}

Allweil, Y. (2007). Shrinking Cities: Like a Slow Motion Katrina. Places, 19(1), 91-93.

Buček, J. (2016). Urban Development Policy Challenges in East-Central Europe: Governance, City Regions and Financialisation. Quaestiones Geographicae, 35(2), 7-26. doi:10.1515/quageo-2016-0012

Buček, J., \& Bleha, B. (2013). Urban Shrinkage as a Challenge to Local Development Planning in Slovakia. Moravian Geographical Reports, 21(1), 2-15. doi:10.2478/mgr-2013-0oo1

Cawley, M.E. (1994). Desertification: Measuring population decline in rural Ireland. Journal of Rural Studies, 10(4), 395-407. doi:10.1016/0743-0167(94)90049-3

Cities Regrowing Smaller (CIRES). (2013). Fostering Knowledge on Regeneration Strategies in Shrinking Cities across Europe. http://www.shrinkingcities.eu (25. 11. 2015).

Clark, D. (1989). Urban Decline. (p. 161). London: Routledge.

Couch, C., Karecha, J., Nuissl, H., \& Rink, D. (2005). Decline and sprawl: an evolving type of urban development - observed in Liverpool and Leipzig1. European Planning Studies, 13(1), 117-136. doi:10.1080/0965431042000312433

Disman, M. (2011). Jak se vyrábí sociologická znalost: Příručka pro uživatele. (p. 372). Praha: Nakladatelství Karolinum. (in Czech).

Fishman, R. (2000). The American metropolis at century's end: Past and future influences. Housing Policy Debate, 11(1), 199-213. doi:10.1080/10511482.2000 .9521367

Ganser, R., \& Piro, R. (2012). Parallel Patterns of Shrinking Cities and Urban Growth: Spatial Planning for Sustainable Development of City Regions and Rural Areas. (p. 283). Burlington: Ashgate.

Haase, A., Rink, D., Grossmann, K., Bernt, M., \& Mykhnenko, V. (2014). Conceptualizing Urban Shrinkage. Environment and Planning A, 46(7), 1519-1534. doi:10.1068/a46269

Haase, A., Bernt, M., Großmann, K., Mykhnenko, V., \& Rink, D. (2013). Varieties of shrinkage in European cities. European Urban and Regional Studies, 23(1), 86-102. doi:10.1177/0969776413481985

Hendl, J. (2008). Kvalitativní výzkum: Základní teorie, metody a aplikace. (p. 407). Praha: Portál. (in Czech).

Hollander, J.B., Pallagst, K., Schwarz, T., \& Popper, F.J. (2009). Planning Shrinking Cities. Progress in Planning, 72(4), 223-232.

Illner, M. (2006). Velikost obcí, efektivita jejich správy a lokální demokracie. In Z. Vajdová, D. Čermák, \& M. Illner (Eds.), Autonomie a spolupráce: Di̊sledky ustavení obecního zřizení v roce 1990. Sociologický ústav AV ČR. (pp. 15-26). Praha. (in Czech).

Krejčí, T., Klusáček, P., \& Lorencová, H. (2009). Je možné přiřazovat Brno a Ostravu mezi tzv. "shrinking cities"?. In Sborník př́spěvku z mezinárodní vědecké konference "Region v rozvoji společnosti 2009”. (pp. 144-150). Brno: Mendelova zemědělská a lesnická univerzita v Brně. (in Czech).

Kupiszewski, M., Durham, H., \& Rees, P. (2008). Internal migration and urban change in Poland. European Journal of Population, 14(3), 265-29o.

Law of Czech Republic. Act no. 128/200o Coll., on Municipalities. (The Municipal Order). (in Czech).

Marotta, S.J. (2011). Creative Reconstruction in the City: An Analysis of Art, Shrinking, and the Story of the American Dream in Detroit, MI. Arizona State University. MA Thesis.

Martinát, S., Dvořák, P., Frantál, B., Klusáček, P., Kunc, J., Navrátil, J., Osman, R., Tureckova, K., \& Reed, M. (2016). Sustainable urban development in a city affected by heavy industry and mining?, Case study of brownfields in Karvina, Czech Republic. Journal of Cleaner Production, 118(1), 78-87.

Ministerstvo pro místní rozvoj ČR. (2013). Strategie regionálního rozvoje $\check{C} R$ 2014-2020. (p. 150). Praha: MMR ČR. (in Czech).

Oswalt, P., \& Rieniets, T. (2007). Global Context. Shrinking Cities, Atlas of Shrinking Cities.

Ouředníček, M., Špačková, P., \& Feřtrová, M. (2011). Změny sociálního prostředí a kvality života $\mathrm{v}$ depopulačních regionech České republiky. Sociologický časopis, 47(4), 777-803. (in Czech).

Popescu, C. (2014). Deindustrialization and Urban Shrinkage in Romania. What Lessons for the Spatial Policy?. Transylvanian Review of Administrative Sciences, [S.l], 42, 181-202. http://rtsa.ro/tras/index.php/tras/article/view/97. (20.12. 2016).

Rink, D., Couch, C., Haase, A., Krzysztofik, R., Nadolu, B., \& Rumpel, P. (2014). The Governance of Urban Shrinkage in Cities of Post-socialist Europe: Polices, Strategies and Actors. Urban Research and Practice, 7(3), 258-277.

Rumpel, P., \& Slach, O. (2012). Je Ostrava “smrštujícím se městem"?. Sociologický časopis, 48(5), 859-878.

Rumpel, P., \& Slach, O. (2014). Shrinkig cities in Central Europe. In J. Koutský, P. Raška, P. Dostál, \& T. Herrschel (Eds.), Transitions In Regional Science - Regions In Transitions: Regional Research In Central Europe. (pp. 142-155). Prague: Wolters Kluwer.

Rumpel, P., Slach, O., \& Boruta, T. (2012). Governance zmenšujících se měst $\mathrm{v}$ Evropském kontextu. In J. Koustký \& P. Raška (Eds.), Výzkum regionál- 
ního rozvoje - vybrané prístupy a témata. Univerzita Jana Evangelisty Purkyně v Ústí nad Labem. (pp. 63-74). Ústí nad Labem. (in Czech).

Rumpel, P., Slach, O., \& Koutský, J. (2013). Shrinking Cities and Governance of Economic Regeneration: The Case of Ostrava. E+M Ekonomie a Management, 11(2), 113-127.

Shetty, S. (2009). Shrinking Cities in the Industrial Belt: A Focus on Small and Mid-size Cities in Northwestern Ohio. (p. 24). Toledo: The University of Toledo.

Schmeidler, K. (2012). Fenomén shrinking cities. Lidé města, 16(1), 125-147.

Schmeidler, K., Jiříčková, H., \& Zámečník, P. (2011). Výzva shrinking cities u nás, $\mathrm{v}$ Evropě i ve světě. Urbanismus a územní rozvoj, 14(6), 21-27. (in Czech).

Silverman, D. (2005). Ako robit kvalitatívny výskum: Praktická príručka. (p. 327). Bratislava: Ikar. (in Slovak).

Stryjakiewicz, T. (2014). The Process of Urban Shrinkage and its Consequences. Romanian Journal of Regional Science, 7, 29-40.

Svobodová, H., Binek, J., Šerý, O., Bárta, D., Chmelař, R., Šilhan, Z., \& Galvasová, I. (2015). Metodika identifikace př́ćin procesu zmenšováni obcí a měst. (p. 29). Brno: GaREP, spol. s r.o. (in Czech).
Svobodová, H., Binek, J., Šerý, O., Chmelař, R., Šilhan, Z., Bárta, D., Szczyrba, Z., \& Galvasová, I. (2015). Zmenšujicí se mèsta a regiony $v$ České republice. Zpráva k projektu. (p. 122). Brno: GaREP, spol. s r.o.. (in Czech).

Sýkora, L. (2012). Rozrůstání města do krajiny. Co $\mathrm{s}$ tím?. Veronica, 26(3), 4-5. (in Czech).

Sýkora, L., \& Ouředníček, M. (2007). Sprawling postcommunist metropolis: Commercial and residential suburbanization in Prague and Brno, the Czech Republic. In E. Razin, M. Dijst, \& C. Vázquez (Eds.), Employment Deconcentration in European Metropolitan Areas: Market Forces versus Planning Regulations. (pp. 209-233). Dordrecht: Springer. 209-233.

Šimon, M. (2014). Exploring Counterurbanisation in a Post-Socialist Context: Case of the Czech Republic. Sociologia ruralis, 54(2), 117-142.

Turok, I., \& Mykhnenko, V. (2007). The Trajectories of European Cities, 1960-2005. The International Journal of Urban Policy and Planning, 24(3), 165-182.

Westlund, H., \& Pichler, W. (2012). The Swedish countryside in the neo-urban knowledge economy. Regional Science Policy \& Practice, 5(2), 225-237. 